\title{
Preliminary Study of Biomonitoring Escherichia coli and Coliform Contamination in Abalone (Haliotis squamata) Cultivation Pond in Musi Village, Gerokgak Sub-District, Buleleng-Bali.
}

\author{
Putu Angga Wiradana*1, Deny Suhernawan Yusup ${ }^{2}$ and Agoes Soegianto ${ }^{3}$ \\ ${ }^{*}$ Graduate School of Biotechnology Fisheries and Marine, Faculty of Fisheries and Marine \\ Science, Airlangga University, Surabaya, Indonesia 60115 \\ Co-Author Email: angga.aquaculture@gmail.com \\ ${ }^{2}$ Faculty of Mathematics and Natural Science, Udayana University, Bali, Indonesia 80361 \\ Second Author Email: dsyusup@yahoo.com \\ ${ }^{3}$ Department of Biology, Faculty of Sciences and Technology, Universitas Airlangga, Surabaya, \\ Indonesia 60115 \\ Corresponding Author Email : agoes_soegianto@fst.unair.ac.id
}

Received: 12 March 2019; Accepted: 23 April 2019

\begin{abstract}
Putu Angga Wiradana, Deny Suhernawan Yusup and Agoes Soegianto. 2019. Preliminary Study of Biomonitoring Escherichia coli and Coliform Contamination in Abalone (Haliotis squamata) Cultivation Pond in Musi Village, Gerokgak Sub-District, Buleleng-Bali. Aquacultura Indonesiana, 20 (1): 32-40. Abalone (Haliotis squamata) is one of the fisheries commodities that have high economic value. This study was conducted to investigate contamination of Escherichia coli and coliform in Abalone cultivation ponds in the Musi Village area, Buleleng Regency, Bali. An experiment was carried out by taking water samples in the abalone pond every week for one month. The results showed that there was no difference between the total number of Escherichia coli and coliform. Water samples that were positive for coliform in the determination test had no differences in each sample with total coliform values (Colonies / $100 \mathrm{~mL}$ ) of 4, 3, 7 and 9 (MPN / 100mL) respectively. While the total number of Escherichia coli is shown after being grown in EMBA selective media which are 4, 3, 7, 4 (MPN / 100mL) respectively. Meanwhile, when compared with the number referenced from the Decree of the State Minister of Environment Number 51 of 2004 concerning Sea Water Quality Standards, the quality of seawater for aquatic cultivation in this study is still classified as Safe (<1000 MPN / 100mL).
\end{abstract}

Keyword : Abalone, Haliotis squamata, Eschericia coli, coliform, Bali

\section{Introduction}

Aquaculture has now made an important contribution to global food production which is needed in terms of supporting the growing population of the world that is estimated to reach 8 billion (USD) by 2028 (U.S. Census Bureau, 2009). According to FAO data (2008) the current production of seafood sourced from fish and shellfish of aquaculture activities has provided as much as $15 \%$ of the annual consumption of animal protein which reaches an average of 2.9 billion people. Indonesia is one of the countries that has potential of large fisheries business in Southeast Asia, there are many marine biota with high economic value. One of them is cultivation of abalone "Haliotis squamata" which can provided considerable benefits to the community and is able to encourage regional income (Atika et al. 2010).

Abalone is included in marine invertebrates that have high economic value. Susanto et al. (2009) stated that in certain areas, the type of abalone Haliotis squamata can be sold at price of $\mathrm{Rp}$. 600,000 . This condition promotes the people to produce abalone which had been 
carried out in several places in Indonesia. Bali is one of the places where abalone shells are produced. According to research reports from Ulinuha and Perwira (2014) states that temporarily abalone from capture results is still a source of abalone shellfish production. One application of Abalone enlargement technology in supporting coastal community empowerment has been done by Rusdi et al (2010) by utilizing seaweed species such as Gracillaria sp. and Euchema cottoni which have been cultivated by coastal communities.

The success of the abalone cultivation has led to an increase in one of the cultivation businesses in the Buleleng Regency, Bali. At the same time, coastal cultivation ecosystems such as abalone can be threatened by pollution and contamination. Problems that are often found from observations of abalone cultivation are the mortality rate of the seed and abalone broodstock is still relatively high, which is around 90\% $94 \%$. This is because the water quality of the media is still inadequate, stocking density is quite high, otherwise it is not supported by good water circulation because due to no application no of biological biofiltration technology, and the appropriate type of feed enrichment is still not yet known (Rusdi et al., 2010). Rearing of abalone in an indoor system is very vulnerable to even mass death which is suspected due to environmental factors caused by the presence of waste produced or decay of abalone mortality. Death of broodstock will cease seed production (Paul, 1980).

Another thing that needs to be considered in the rearing of abalone is to comply the optimum environmental parameters and prevent any deterioration in the environmental quality which can result in disruption the growth of abalone. Decreasing quality of the aquaculture environment can cause abalone to become stress and can cause mortality, which may become the causative of experimental degradation. Carcase can become one of the causes of environmental degradation (Rusdi et al., 2010). According to Harris et al. (1998), the presence of feces in the nursery causes a decrease in water quality that can impact the abalone appetite. Feces is one parameter that can reduce the growth rate of abalone and even cause death (Chang et al., 2004). The presence of feces in abalone maintenance water will cause an increase in the presence of bacteria that can cause disease and ammonia is a poison that can cause death in abalone (Rusdi et al., 2010).

Based on the above, the purpose of this study was to obtain information on the biomonitoring efforts of abalone shellfish health by measuring water quality parameters, in particular, the number of Escherichia coli and Coliform in indoor cultivation systems. The results of this study are expected to provide information to the public to maintain biological indicators, especially environmental problems that can affect the quality of aquatic animal health and culture for abalone shellfish cultivation.

\section{Materials and Methods}

\section{Water Sampling}

Water samples were taken from abalone cultivation ponds in Musi Village, Gerokgak, Buleleng-Bali, which applied an indoor cultivation system. The location map can be seen in Figure 1.

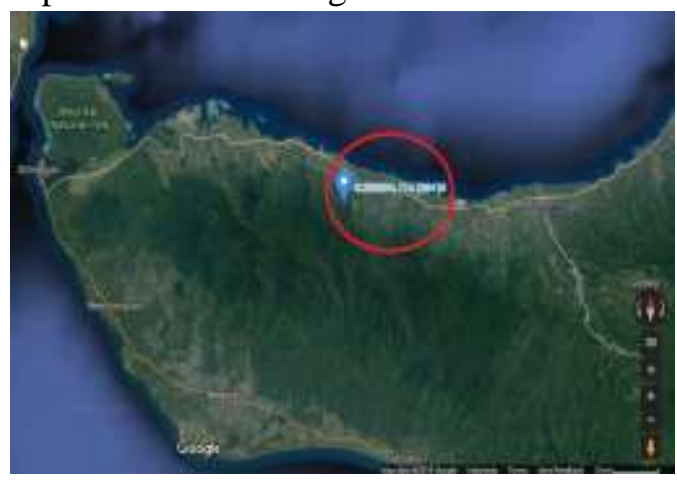

Figure 1. Sampling locations in Musi Village, Gerokgak Sub-District, Buleleng-Bali (Google Maps)

Water sampling were collected periodically weekly within a month of observation period to enumerate the total amount of E. coli and coliform contained in the water in the indoor abalone system. Water sampling was carried out aseptically in a composite abalone pond and stored in a sterile bottle $(150 \mathrm{~mL})$ (Figure 2). Then the sample bottles are labeled and stored in 
a cooling box to prevent changes in the parameter during transportation to the laboratory.

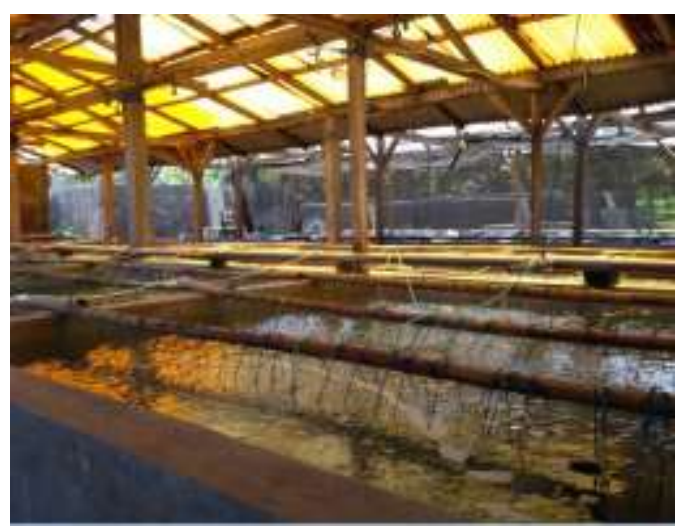

Figure 2. Abalone (Haliotis squamata) cultivation ponds indoor in Musi Village

\section{Preparation Media and Sterilization}

\section{- Lactose Broth (LB)}

LB media was made in two different concentrations namely single strength and double strength. Media with a normal concentration (single strength) was made by weighing $3.08 \mathrm{gr} \mathrm{LB}$ and dissolved in $200 \mathrm{~mL}$ of distilled water. Media LB double concentration (double strength) was made by weighing 3.9 gr LB and dissolved in $150 \mathrm{~mL}$ aquades. The two media were then heated on the hot plate to boil. The two boiling media were then cooled at room temperature, then poured in test tubes with that contained a Durham tube.

\section{- Brilliant Green Bile $2 \%$ Broth (BGBLB)}

BGBLB media were made by dissolving 4.00 gr BGBLB in $200 \mathrm{~mL}$ of distilled water. The media were then heated to boiling point on the hot plate. After the media temperature has decreased, the media is poured into a small test tube containing the Durham tube.

\section{- Eosin Methylene Blue Agar (EMBA)}

EMBA media were made by dissolving 3.62 gr EMBA in $100 \mathrm{~mL}$ of distilled water, then heated with a hot plate to boil.

\section{- Sterilization}

To avoid contamination, sterilization of the tools and materials used in this experiment was done using autoclave. All materials such as LB media, BGBLB media, EMBA media, and tools that have been packed with plastic such as Petri dishes, test tubes, and tips were put into the autoclave, then sterilized for 15 minutes at a pressure of $15 \mathrm{lbs}$ and at $121^{\circ} \mathrm{C}$. After the sterilization process finished, the media were stored in the refrigerator and all the tools were stored in the oven.

\section{Calculation of Total Coliform and Escherichia coli}

Calculation of total Coliform and Escherichia coli was carried out using the Most Probable Number (MPN) tube 333 methods which included three stages, namely the Presumptive test, Confirmed test, and the Completed test.

\section{a) Presumptive Test}

Differential medium for isolation of coliforms was Lactose Broth and BGBLB. Three broth tube series, the first series containing 3 double strength broth tubes and the remaining two series comprising 6 single strength broth tubes were inoculated with $10 \mathrm{~mL}, 1 \mathrm{~mL}$ and $0,1 \mathrm{~mL}$ of water sample (ratio 3:3:3) respectively (Akeju and Awojobi, 2015).

Prepared 9 test tubes containing Lactose Broth (LB) media and Durham tubes inside upside down. The first three tubes were filled with LB media with double concentrations, then each was inoculated with $10 \mathrm{~mL}$ sample. The second group of three tubes were filled with single strength LB media and each was inoculated with $1 \mathrm{~mL}$ sample. Whereas the last three tubes were filled with a single LB medium and suspended $0.1 \mathrm{~mL}$ of the sample in the test tube, then all tubes were incubated at $37{ }^{\circ} \mathrm{C}$ for 24 hours.

The presumptive test is positive for Coliforms if acid and gas are produced in Durham tubes containing Lactose Broth media. 


\section{b) Confirmed Test}

Samples showing positive results on the presumptive test were then inoculated into the BGBLB medium containing the Durham tube using an ose needle. Then incubated into an incubator at $37{ }^{\circ} \mathrm{C}$ for 24 hours. Positive results are indicated by the formation of gas bubbles in the Durham tube. A loop of bacterial culture in BGBLB medium (of positive tubes) was streaked on the Eosin Methylene Blue Agar (EMBA) medium and then incubated at $37{ }^{\circ} \mathrm{C}$ for 24 hours. Positive results on EMBA media are indicated by the presence of "metallic green" bacteria colonies. Calculation of the total number of Escherichia coli in Petri dishes was carried out by looking at the table of the "World Health Organization: Water Sanitation Health" Most Probable Number (MPN) (Figure 3).

\begin{tabular}{|c|c|c|c|c|c|}
\hline \multicolumn{3}{|c|}{ Na. of tubes giving a postive reaction } & \multirow[t]{2}{*}{$\begin{array}{l}\text { MPN (jor } \\
100 \mathrm{mil} \text { ) }\end{array}$} & \multicolumn{2}{|c|}{$\begin{array}{l}\text { 95\% contidence } \\
\text { limits }\end{array}$} \\
\hline 3 of $10 \mathrm{mi}$ & $3 d i=1$ & 3 of $0.1 \mathrm{ml}$ & & Loenr & Upper \\
\hline 0 & 0 & T & 3 & $<1$ & 9 \\
\hline 0 & 1 & 0 & 3 & $<1$ & 13 \\
\hline 0 & 2 & 0 & 4 & $<1$ & 20 \\
\hline 1 & 0 & 1 & 7 & 1 & 24 \\
\hline 1 & $\uparrow$ & 0 & 7 & 1 & 23 \\
\hline 1 & 1 & $i$ & 11 & 3 & 36 \\
\hline 1 & 2 & a & 11 & 3 & 36 \\
\hline 2 & 0 & 0 & 9 & 1 & 36 \\
\hline 2 & 0 & 1 & 34 & 3 & $\pi$ \\
\hline 2 & 1 & 0 & 15 & 3 & 4 \\
\hline 2 & 1 & t & 20 & 7 & 49 \\
\hline 2 & 2 & 0 & 21 & 4 & at \\
\hline 2 & 2 & 1. & 28 & 10 & 149 \\
\hline 3 & 0 & 0 & 23 & 4 & 120 \\
\hline 3 & 0 & $\mathrm{t}$ & 39 & 7 & 130 \\
\hline 3 & 6 & 2 & 64 & is & 327 \\
\hline 3 & 1 & 0 & 48 & 7 & 210 \\
\hline 3 & 1 & 1 & 75 & 14 & 230 \\
\hline 3 & 1 & 2 & 120 & 30 & 980 \\
\hline 3 & 2 & 0 & 193 & 15 & 300 \\
\hline 3 & 2 & 1 & 150 & 30 & 440 \\
\hline 3 & 2 & 2 & 210 & 35 & 470 \\
\hline 3 & 3 & 0 & 249 & 36 & 1300 \\
\hline 3 & 3 & 1 & 400 & 71 & 2400 \\
\hline 3 & ja & 2 & 1100 & 150 & 4800 \\
\hline
\end{tabular}

Figure 3. MPN values per $100 \mathrm{~mL}$ of the sample and $95 \%$ confidence limits for various combinations of positive and negative results (when three $10-\mathrm{mL}$, three $1-\mathrm{mL}$ and $0.1-\mathrm{mL}$ test portions are used) (www.who.int.)

\section{c) Completed Test}

Bacterial colonies that showed positive results on EMBA media were then tested further by Gram staining method. The purpose of the Completed test is to confirm whether the colonies on EMBA were Eschericia coli. Bacterial smears were fixed on glass objects by quickheating over the Bunsen flame. Then the
Violet Crystal dye was poured for 1.5 minutes and washed with distilled water and dried. After drying, smear the glass with Lugol's solution and let stand for 1 minute. Then, treat with $95 \%$ alcohol drops for 30 seconds, washed with distilled water, and dried. Dyed the slide with Safranine preparations for 15 minutes then washed with distilled water and dried (Figure 4).

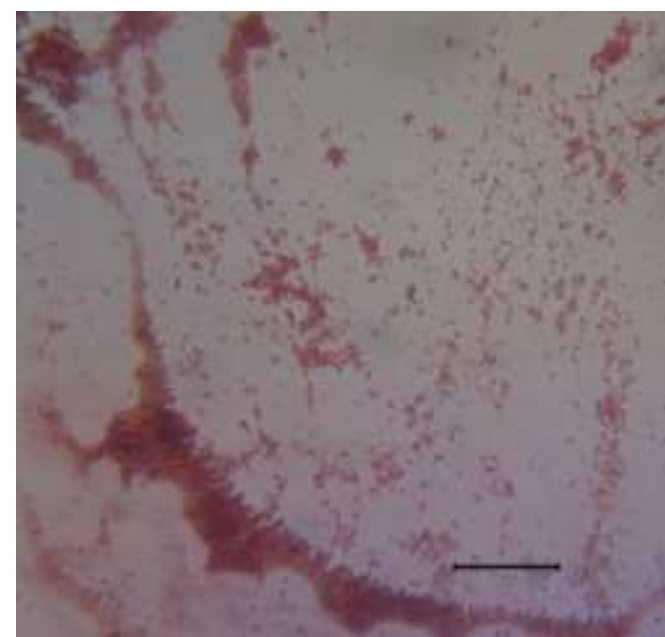

Figure 4.The results of the completed test showed Escherichia coli in the form of a rod. Scale bar $=10$ $\mu \mathrm{m}$.

\section{Water Quality}

Measuring water quality parameters in the rearing tank is carried out every time a water sample is taken. The measured water quality consists of several parameters including salinity, temperature, dissolved oxygen (DO), $\mathrm{pH}$, nitrite and ammonia (Table 2.)

\section{Data Analysis}

The data obtained are included in semi-quantitative data, namely data based on description scales in qualitative analysis by giving values to each analysis based on the Most Probable Number (MPN) table. Water quality was analyzed descriptively to explain the feasibility of rearing media for the cultivation of abalone with indoor systems which are presented in table form.

\section{Results}

The results of the Presumptive test observations from the four water samples 
are shown in Table 1. The positive results indicated by the presence of "gas bubbles" on the Durham tube on the media will be followed by a Confirmed test on BGBLB (Brilliant Green Bile 2\% Broth) media. The four Confirmed test results of the water samples are shown in Figure 5.

The highest number of coliforms was found in W4 sample (4th week) which was equal to 9 colonies $/ 100 \mathrm{~mL}$ and $\mathrm{W} 3$ (3rd week) at 7 colonies $/ 100 \mathrm{~mL}$ while the lowest number of coliforms was found in W2 samples (2nd week) which was equal to 3 colonies / $100 \mathrm{~mL}$. For sample W1 (1st week) there is a number of coliforms that is equal to 4 Colonies / $100 \mathrm{~mL}$.

The highest number of Escherichia coli colonies was found in the $\mathrm{W} 3$ sample which was 7 colonies / $100 \mathrm{~mL}$ and W4 and $\mathrm{W} 1$ for 4 colonies / 100mL while the lowest number of coliforms was found in the W2 sample which was 3 colonies / 100 $\mathrm{mL}$.

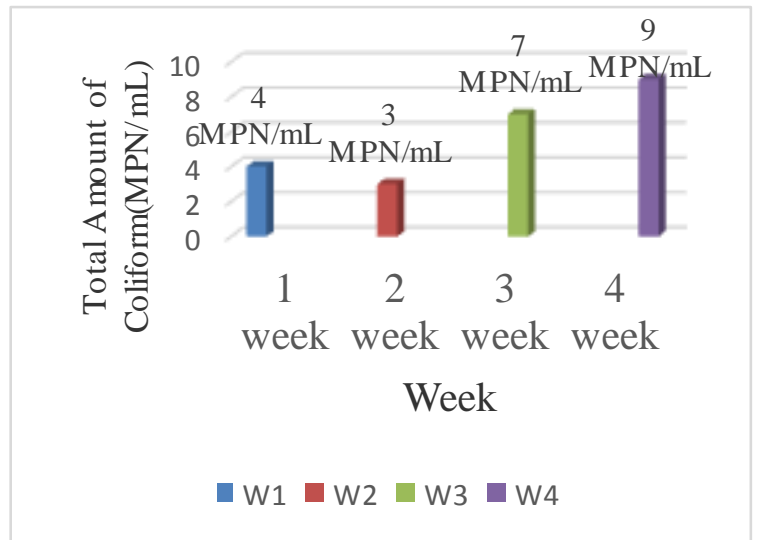

Figure 5. Total Amount of Coliform (MPN/mL) on Brilliant Green Bile 2\% Broth medium.
The results of the Completed test can be seen in Figure 6. Bacterial colonies that showed positive results on EMBA media were then tested further by Gram staining method (Figure 4.). The results of the observation show that after Gram staining, it can be seen that there are Escherichia coli colonies in water samples, although still in tolerable amounts.

The results of measurements of water quality for each sampling on rearing media are presented in Table 2. Water quality measurements are used to support the results of the study and explain the sanitary conditions applied in the business of indoor abalone cultivation. The measurement results showed that water quality parameters including salinity, temperature, $\mathrm{DO}, \mathrm{pH}$, nitrite and ammonia rearing media at each sampling were still within the tolerance limit to support survival rate of abalone and growth.

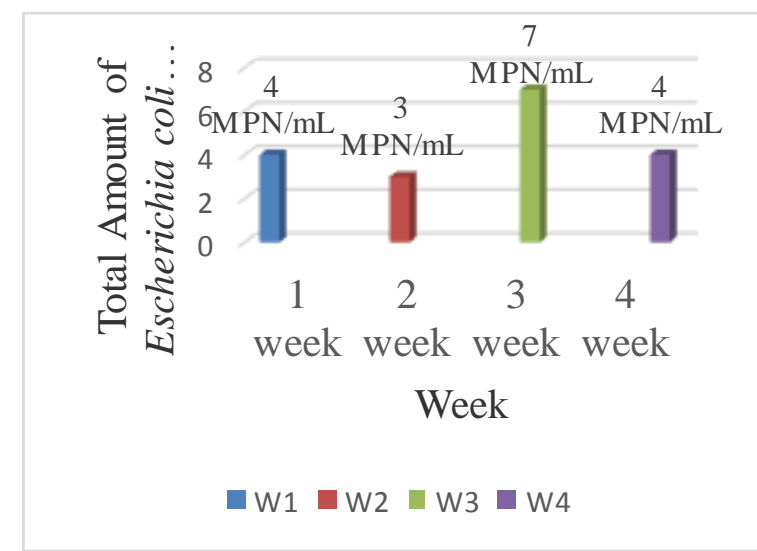

Figure 6. Total Amount of Escherichia coli (MPN/mL) on selective Eosin Methylene Blue Agar medium

Table 1. The result Presumptive test of water samples on Lactose Broth media

\begin{tabular}{|c|c|c|c|c|}
\hline \multirow{5}{*}{ Sample } & & $\mathbf{f} w$ & & \multirow{5}{*}{ MPN per $100 \mathrm{~mL}$} \\
\hline & 10 & 1 & 0.1 & \\
\hline & \multicolumn{3}{|c|}{ No. of samples of each quantity tested } & \\
\hline & 3 & 3 & 3 & \\
\hline & \multicolumn{3}{|c|}{ Number of tubes giving positive reactions (acid and gas) } & \\
\hline W1 & 1 & 3 & 1 & 11 \\
\hline W2 & 3 & 2 & 1 & 150 \\
\hline W3 & 3 & 3 & 2 & 1100 \\
\hline W4 & 3 & 1 & 0 & 48 \\
\hline
\end{tabular}

Noted : W1 $=1^{\text {st }}$ week; W2 $=2^{\text {nd }}$ week; W3 $=3^{\text {rd }} ; \mathrm{W} 4=4^{\text {th }}$ 
Table 2. Result water quality parameter values on abalone (Haliotis squamata) rearing media with indoor cultivation systems.

\begin{tabular}{|c|c|c|c|c|c|}
\hline \multirow[t]{2}{*}{ Parameter } & \multicolumn{4}{|c|}{ Water quality parameter values during sampling } & \multirow[t]{2}{*}{ Optimal range } \\
\hline & $1^{s t}$ week & $2^{\text {nd }}$ week & $3^{\text {rd }}$ week & $4^{\text {th }}$ week & \\
\hline Salinity (ppt) & 31 & 31 & 32 & 31 & $\begin{array}{l}30-33 \text { ppt } \\
\text { (Setyono, 2010) }\end{array}$ \\
\hline $\begin{array}{l}\text { Temperature } \\
\left({ }^{\circ} \mathrm{C}\right)\end{array}$ & 24,0 & 23,8 & 24,4 & 25,1 & $\begin{array}{l}20-32 \\
\text { (Pratama, 2013) }\end{array}$ \\
\hline $\begin{array}{l}\text { Dissolved } \\
\text { Oxygen }(\mathrm{mg} / \mathrm{L})\end{array}$ & 5,57 & 5,86 & 6,86 & 6,78 & $\begin{array}{l}5,7-7,6 \\
\text { (Hamzah et al. } \\
\text { 2012) }\end{array}$ \\
\hline $\mathrm{pH}$ & 8,2 & 8,5 & 8,6 & 8,6 & $\begin{array}{l}7,5-8,5 \\
\text { (Setyono, 2010) }\end{array}$ \\
\hline Nitrite (mg/L) & 0,0021 & 0,0068 & 0,0088 & 0,0097 & $\begin{array}{l}<1 \mathrm{mg} / \mathrm{L} \\
\text { (Tahang et al. } \\
\text { 2006) }\end{array}$ \\
\hline $\begin{array}{l}\text { Ammonia } \\
(\mathrm{mg} / \mathrm{L})\end{array}$ & 0,0055 & 0,0080 & 0,0066 & 0,0060 & $\begin{array}{l}<0,5 \mathrm{mg} / \mathrm{L} \\
\text { (Susanto et al. } \\
2010 \text { ) }\end{array}$ \\
\hline
\end{tabular}

\section{Discussion}

Abalone (Haliotis squamata) is one of the fisheries commodities that have high economic prospects and value as well as a fairly good market share. Along with the depletion of abalone in nature, the abalone cultivation development business has increased in several countries such as the United States of America, Mexico, South Africa, Australia, Japan, China, Taiwan, Ireland, Iceland, and others. Currently, the largest producer of abalone cultivation in the world is China which has more than 300 farms and total production value of 3,500 tons, most of which are Haliotis diversicolor supertexta species (Gordon and Cook, 2001).

At present, the abalone cultivation system has been carried out indoors, but the cultivation still has major obstacles such as limited stock, abalone types which have slow growth and are susceptible to environmental changes that cause low productivity. Indicators that can be used to determine the potential growth rate of abalone is the water quality in cultivation (Tasruddin, 2012).

Water quality can be determined by determining biological parameters such as Based on the results of the calculation of the total E. coli and coliform in the water samples which were taken periodically there was a different total number of $E$. coli and coliform bacteria. The presence of bacteria in water samples at the presumptive in the Lactose Broth media were indicated by the formation of gas in the Durham tube and the color change in the media.

The presence of coliform bacteria in water samples, can be assumed to originate from the outside environment because the water used is not filtered by membrane filter or sterilized with UV light or ozonation, but only filtered with sand so that bacteria can enter through water circulation. The presence of coliform bacteria in the waters can be used as an indicator of aquatic pollutants (Hrenovic and Tomislav, 2009). Ristori et al. (2007) conducted a similar evaluation by determining the level of pathogenic bacteria and the presence of coliform in the oyster (Crassostrea rizophorae) culture system.

According to the Ministry of Environment of the Republic of Indonesia (2004), the content of the total number of coliform bacteria in aquaculture water must be below 1000 colonies / 100mL. The location of abalone cultivation in Musi Village which has good seawater and water circulation system generally has a very small or even zero total coliforms bacterial concentration. According to Kunarso 
(1989), the presence of a total number of coliform bacteria can be an indicator of the entry of fecal contaminants in aquaculture pond environments. According to Rusdi et al (2010) organic matter consisting of residual feed and abalone feces is a relatively degradable material, and in the decomposition process would produce toxic materials such as ammonia, nitrite, sulfide acid and bacteria. These inorganic compounds have a role in promoting the increase in bacterial population because these particles act as a source of energy for bacteria.

Positive results on water samples in the coliform test will be continued by calculating the total number of Escherichia coli in water samples by inoculating (Streak for Single Colony) the sample in EMBA which is a selective medium for the growth of Escherichia coli. According to Suhendar and Heru (2007), Salmonella sp. and Escherichia coli bacteria can cause diseases, decay, and toxins that cause marine biota such as abalone to die. In general, there are three groups of pathogenic bacteria in shellfish. First are native bacteria as natural microflora, for example Clostridium botulinum, Vibrio spp., Aeromonas hydrophila. The second is enteric bacteria that is present because of fecal contamination such as Salmonella spp., Shigella spp., Escherichia coli, Staphylococcus aureus. The third is a group of bacteria formed by post-harvest such as Bacillus cereus, Listeria monocytogenes, Staphylococcus aureus, Clostridium perfringens and Salmonella spp (Lyhs U. 2009).

The right water exchange system, besides being able to maintain water quality from various diseases, can also minimize stress conditions on abalone, so that environmental conditions remain in optimal condition and promote the growth of abalone (Tasruddin, 2012). According to Soderberg (1995) states that water exchange can encourage the use of feed, minimize dirt and metabolites in maintaining good conditions for growth. However, most solid waste can settle and accumulate in the lower part of the water stream. According to Lawrence (1995) and Mozqueira (1996) states that abalone naturally adapts to turbulent sea conditions and flowing water and the importance of maintaining temperature, $\mathrm{pH}$, dissolved oxygen and salinity in supporting abalone survival and growth. A change of 5-10\% of water can be carried out continuously to control the cultivation environment (Masser et al. 1999).

The low total number of E. coli bacteria in aquaculture ponds due to the small amount of fecal waste that can enter the abalone or $E$. coli maintenance ponds cannot last long because of the high salinity (> 30\%). According to Ruyitno and Hatmanti (2008), in this salinity, the coliform bacteria and E. coli can only last a few hours so that only certain bacteria can adapt to fairly high salinity. Such conditions can also be caused by concentrations of organic matter, changes in salinity, and temperature and light intensity. Things that need to be considered in maintaining the water quality of abalone cultivation are stocking densities. Increased stocking density can result in a decrease in water quality due to an increase in ammonia and a decrease in oxygen dissolved in water. Ammonia and nitrite values during sampling are still within the safe limits of abalone adjusted by the study conducted by Susanto et al. (2010) and Ardyansyah (2017) of <0.5. The increase in ammonia value along with nitrite can cause stress on the organism of cultivation, decrease growth and support the growth of pathogenic bacteria. However, the use of indoor cultivation systems in this study can maintain water quality that can support the results of biomonitoring (total coliform and Eschericia coli).

In general, it is known that efforts to maintain aquaculture water quality are very important. In addition to toxic, heavy metals and organic pollutants that can have an impact on the safety of abalone that is cultivated for human consumption, abalone shellfish farmers are also directly affected by pollution that affects the growth of shellfish. The contamination of waters and environmental degradation may also harm the economy of coastal cities, and negatively affect tourism and compromise fisheries in Buleleng, Bali (Collins et al. 1998). These results of this preliminary study may indicate that simple diagnose of 
environmental conditions in the abalone cultivation system in Musi Village, Buleleng Regency, Bali, is due to the level of contamination throughout the year, and because contaminants can accumulate in marine biota, especially "filter feeder" organisms such as for as Abalone. Therefore, further research is needed in monitoring of water quality in abalone cultivation to improve its productivity. Public awareness about environmental pollution issues and the application of regulations that can affect the aquaculture environment must be carried out in the marine fisheries sector to demonstrate commitment in maintaining the biological integrity of the environment that farmers use for the cultivation of abalone shellfish.

\section{Acknowledgment}

We would like to thank the Abalone Shellfish Cultivation Farmers in Musi Village, Gerokgak Sub-district, BulelengBali for giving permission to carry out this research. Appreciation to the Head of the Microbiology Laboratory, Faculty of Mathematics and Natural Sciences, Udayana University for their kind assistance in conducting this research.

\section{References}

Akeju, T.O and Kehinde, O.A. 2015 Enumeration of coliform bacteria and characterization of Eschericia coli isolated from Staff Club swimming pool in Ile-Ife, Nigeria. Microbiology Research (6): 1

Ardyansyah, I. 2017. Abalone (Haliotis squamata) Production Performance in Recirculating Systems with Stocking Densities at 100, 200 and 300 tails/M². SKRIPSI. Department of Aquaculture, Faculty of Fisheries and Marine Sciences, Bogor Agricultural University (IPB University).

Atika., Rusliadi, and Mulyadi. 2010. Growth And Survival Rate of Abalone (Haliotis squamata) on Different Stocking Density.J. Ilmiah Aquaculture of Technology 4 (2): 1-8.

Chang, W., Hsiao I. Shan., J.C.Chen. 2004. Effect of Ammonia on the Immune Response of Taiwan Abalone Haliotis diversicolor supertexta and its
Susceptibility to Vibrio parahaemolyticus. J. Fish \& Shellfish Immunology. Volume 17: 193-202.

Collins, A., Stapleton, M., Whitmarsh, D. 1998. Fishery-pollution interactions: a modeling approach to explore the nature and incidence of economic damages. Marine Pollution Bulletin (36):211-221

Food and Agriculture Organization of the United Nations (FAO). 2008. The State of World Fisheries and Aquaculture 2008. Technical Fisheries Bulletin. Fisheries and aquaculture department.FAORome(2009).www.fa o.org/docrep/011/i0250e00.htmFAO

Gordon, H.R and P. Cook. 2001. World abalone supply, markets, and pricing: historical, current and future. Shellfish Research. 20(2): 567-570.

Hamzah, M.S., Dwiono, S.A.P and Hafid, S. 2012. Growth and Survival Rate of Tropical Abalone Snail (Haliotis asinine) in Concrete Tanks at Different Densities. Jurnal Ilmu dan Teknologi kelautan Tropis. 4(2): 191197.

Harris, O, J. Maguire G, B, Edwards S, Hindrum, M, S. 1998. Effect of ammonia on the Growth Rate and Oxygen Consumption of Juvenile Greenlip Abalone, Haliotis laevigata Donovan. J. Aquaculture, Volume 160: 256-272.

Hrenovic dan Ivanovic. 2009. Survival of Escherichia coli and Acinetobacter junii at Various Concentration of Sodium Chloride. Eur. Asia J. BioSci., 3:144-151.

Kementerian Lingkungan Hidup RI. 2004. Decree of the Minister of Environment, No.51 of 2004 concerning Sea Water Quality Standards. In: a collection of coastal and marine damage control regulations, subchapter seawater quality standards. Jakarta. Appendix III. Pp: 20-26.

Kunarso, D.H. 1989. Membrane Filter Technique for Detecting Pollutant Bacteria. Oceana, 4: 133-143.

Lawrence, C. 1995. Greenlip, Brwonlip and Roe's abalone. Aquaculture WA, No.7. Fisheries Department of Western Australia. 4-pp.

Lyhs, U. 2009. Microbiological Methods: Fishery Products Quality, Safety and Authenticity. Chapter 15 pp 318-348

Masser, M.P., Rackocy, J and Losordo, T.M. 1999. Recirculating aquaculture tank production systems: management of 
recirculating systems. Southern Regional Aquaculture Center, Publicationno.

Mozqueira, A. 1996. Site selection for land based abalone farming. In: Forster, A.(Ed). Proceedings of the Abalone Aquaculture Workshop, December, 1995, Albany, Western Australia. Aquaculture Development Council and Fisheries Department of Western Australia. Pages. 17-21.

Paul, J.D. 1980. Salinity-temperature Relationships in the Green Scallop Chlamys opercularis. J. Mar. Biol. 56: 295-300.

Pratama, I.S. 2013. The Effect of Dense Stocking on the Growth and Survival Rate of Juvenile Abalone (Haliotis asinine) in Recirculation Systems Using Rice Husk Biofilter. SKRIPSI. Depok: Universitas Indonesia.

Ristori, C.A.,Iaria, S.T.,Gelli, D.S.,Rivera, I.N.G. 2007. Pathogenic bacteria associated with oysters (Crassostrea brasiliana) and estuarine water along the south coast of Brazil. International Journal of Environmental Health Research, (17):259-269.

Rusdi, I., A. Hanafi., B. Susanto and M.Marzuqi. 2010. Increased Synthesis of Abalone Seeds (Haliotis squamata) at Hatchery Through Optimization of Feed and Environment. Final Report of the Research Research and Engineering Enhancement Capability Incentive Program of the National Research Council of the Ministry of Research and Technology. BBRPBL, GondolBali.

Ruyitno, N. and A. Hatmanti. 2008. Microbiological Conditions of Kuala Tungkal Waters, Jambi as Blood Shellfish Cultivation Habitat (Tegilarea granola). Research Center for Oceanology-LIPI. Pages: 183-192.
Setyono, D.E.D. 2010.Abalone: Hatchery Technology. ISOI: Jakarta.

Soderberg, R.W. 1995. Flowing Water Fish Culture. CRC Press, Boca Raton, Florida.

Suhendar, I.S dan D.W. Heru. 2007. Environmental pollution conditions. Waters in Jakarta Bay, 3 (1): 38-44.

Susanto, B., Rusdi, I., Ismi, S and Rahmawati, R. 2010Rearing of yuwana Abalone (Haliotis squamata) Controlled F-1 Derivates with Different Types of Feed. Jurnal Riset Akuakultur. 5(2): 199-209.

Susanto, B., Rusdi, I., Ismi, S., and Rahmawati, R. 2009. Abalone seeding and enlargement (Haliotis squamata) at Gondol Research Center for Marine Aquaculture, Bali. In Proceedings of the Molluscs 2 National Seminar, "Molluscs Business Opportunities and Conservation". FPIK, IPB. Bogor: 149-161

Tahang, M., Imron and Bangun. 2006. Rearing of Abalone Shellfish (Haliotis asinine) with pen-culture method (kurungan tancap) and Floating Net Cages (KJA).Lombok Sea Cultivation Center. Directorate General of Fisheries.

Tasruddin. 2012. Production and Quality Performance of Haliotis squamata Abalone with Water Flow Through Replacement Systems. Thesis. Postgraduate School, Bogor Agricultural University. Bogor.

U.S.Census Bureau. 2009. Population Division.www.census.gov/ipc/www/id b/index.php

Ulinuha, D and I.Y, Perwira. 2014. Biomonitoring Health of Abalone Shellfish (Haliotis squamata) Captured in Mengening Waters, Bali with Observation on Phagocytic Activity. Research Report for Young Lecturers, FKP, Udayana University. Bali. 